\title{
The human impact in the German Bight: Eutrophication during three decades (1962-1991)
}

\author{
W. Hickel, P. Mangelsdorf \& J. Berg \\ Biologische Anstalt Helgoland, Notkestr. 31, D-22607 Hamburg, \\ Federal Republic of Germany
}

\begin{abstract}
The human impact in the German Bight, in the form of anthropogenic eutrophication, has been documented by a 30-year time-series measurement near the island of Helgoland. Since 1962, the Biologische Anstalt Helgoland has measured inorganic nutrients and phytoplankton abundance from daily samples at Helgoland Roads, a position $60 \mathrm{~km}$ off the main source of eutrophication, the River Elbe. Since the early 'sixties, phosphate concentrations rose for about a decade, levelling off to about twice the former concentrations for another decade, and then decreasing (since 1982) as a result of phosphate-reducing measures. Nitrate concentrations, however, have only increased since 1980/81, following Elbe river flood events. In 1987, three times the former concentrations were reached. A decrease has been observed only since 1991. This different development of phosphorus and nitrogen eutrophication led to a shift of inorganic N/P-ratios in the German Bight. The phosphate increase was more pronounced in the late summer "regeneration mode" conditions, the nitrate increase in the winter months. The eutrophication is not restricted to the inner German Bight and coastal waters of a salinity of $<33$, but has also occurred in more saline waters at $S>33$ psu (practical salinity unit), as characteristic for the outer German Bight. In this more saline water, phosphate and nitrate maximum levels occurred three years later, compared with the average Helgoland data, which are more representative of the inner German Bight. It is suggested that suspended particulate organic matter, as a long-distance carrier of nutrients, might have caused this delayed eutrophication in the outer German Bight waters. While the human impact is obvious as to nutrient concentrations, it is less obvious in phytoplankton stock enhancement. A general increase in phytoplankton biomass (about 3-4 times) was found, but this was mainly due to unidentified nanoflagellates of unknown trophic state, and subject to methodological errors. The causal relationships of phytoplankton stocks and eutrophication are not clearly understood, as natural variability is large and hydrographical factors possibly dominate. Additional nutrient input by Elbe river floods did not always result in elevated phytoplankton stocks near Helgoland, while extended periods of vertical density stratification of the German Bight water caused large plankton blooms.
\end{abstract}

\section{INTRODUCTION}

The human impact in the German Bight depends not only on the local riverine inputs, but also on the volume of the coastal water and on the residual current system of the southern North Sea. The position of the estuaries of the main rivers that drain central Europe, along with the counterclockwise residual current pattern which carries riverborne substances from west to east, favour the accumulation of eutrophying substances in the German Bight. Local and distant sources, and the relatively small water volume make the shallow German Bight a major (and probably the most extensive) eutrophied area of the North Sea. Reviews such as Gerlach (1990), Brockmann et al. (1988), and Nelissen \& Stefels (1988) describe the hydrographical and nutrient situation of the southern North Sea. 
Since 1962, the Biologische Anstalt Helgoland has continuously measured inorganic nutrients and phytoplankton near Helgoland, a small island in the German Bight (Fig. 1), about $60 \mathrm{~km}$ north west of the Elbe river estuary, which is the main source of freshwater.

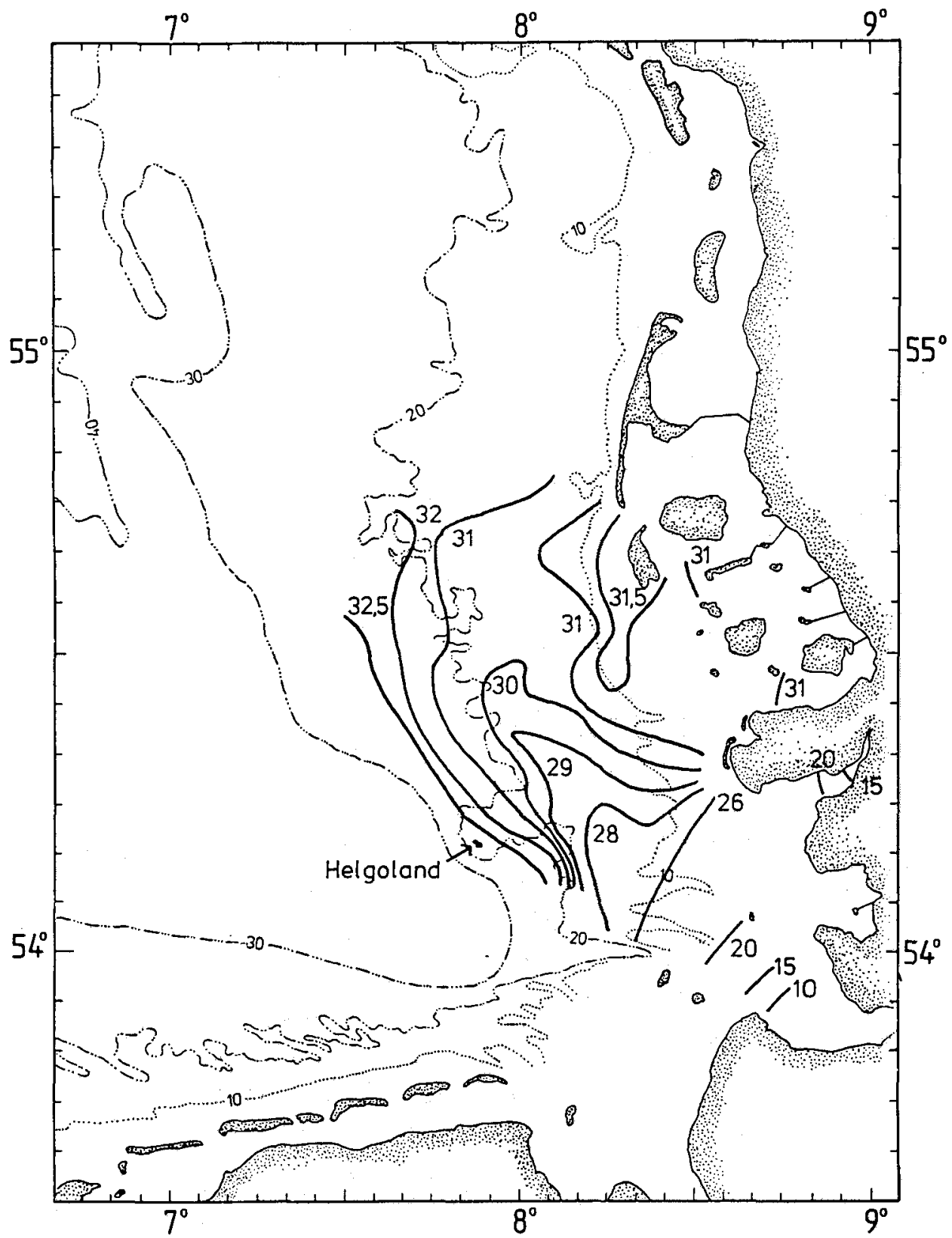

Fig. 1. The German Bight with the island of Helgoland (monitoring station). Salinity isopleths show the Elbe river water plume after a flood event in 1954 (Kalle, 1956), depicting the typical situation of a particularly large fresh water inflow into the German Bight 
Figure 1 includes the isopleths of surface salinities, which show the characteristic spreading of the Elbe river water plume after a large river flood event. This example from Kalle (1956) was chosen because of the close spacing of sampling stations, optimally covering the river plume. This flood event shows that the river plume extends between the peninsula of Eiderstedt and the island of Helgoland; the Helgoland Roads sampling station is easily reached by the river plume, should the wind turn to an easterly direction.

The Helgoland Roads time-series is one of the longest - and certainly the one with the shortest time-intervals - of the data sets from the North Sea; it provides an adequate data set to describe and evaluate the eutrophication process in the German Bight. The Helgoland data have been analyzed by Lucht \& Gillbricht (1978) with respect to nutrients in relation to Elbe river input, and Hagmeier (1978) for the phytoplankton up to 1974. Gillbricht (1983) investigated a plankton bloom event and he also (1988) analyzed nutrient and phytoplankton dynamics up to 1986. Radach \& Berg (1986) and Radach et al. (1990) used the data up to 1984 for trend analyses; Radach \& Bohle-Carbonell (1990) analyzed the structure and variability of the Helgoland data along with meteorological data.

Major changes in nutrient concentrations and ratios have occurred during the last decade - not covered by the above publications - in the German Bight. These were obviously a result of human interference. The present paper describes the changes in eutrophication of the seawater near the island of Helgoland during a period of 30 years of continuous measurements.

\section{METHODS}

Since 1962, time-series measurements of inorganic nutrients, phytoplankton stocks and hydrographical parameters have been carried out at Helgoland Roads ( $54^{\circ} 11.3^{\prime} \mathrm{N}$, $7^{\circ} 54.0^{\prime} \mathrm{E}$ ), a narrow channel between the main island of Helgoland and a small, sandy island nearby. Normally at $9.00 \mathrm{~h}$ in the morning, surface water samples are taken from a boat. These samples were taken to be representative of the water column of only $5 \mathrm{~m}$ depth, as strong tidal currents mix the water column. Salinity and temperature were determined 5 times per week from workday samples; nutrients and plankton 3 times per week until 1974 , and five times per week since 1975 . Silicate has been measured since 1966.

Salinity was measured with an inductive salinometer (except for the first years, when chloride titration was used). Inorganic nutrients were analyzed using standard methods according to Grasshoff et al. (1983), with some modifications. Water samples were analyzed for nutrients immediately after sampling, except for silicate which was analyzed from deep-frozen samples.

The microplankton was counted with an inverted microscope after fixation with neutralized Lugol's iodine solution. The determination was done to the species or genera level, sometimes to higher taxonomic levels as the fixed material and fast counting procedure do not allow better identification. This was particularly true for the minute, naked nanoflagellates. Counted plankters were converted to organic carbon, using factors calculated from size and shape of the species based on Hagmeier (1961). These biomass values were summed up for diatom and non-diatom (= "flagellate") plankton, or basically nonmotile and motile phytoplankton. The "flagellates" thus included various taxonomic groups, of which the dinoflagellates dominated in biomass. 


\section{RESULTS}

Monthly median values were used for annual cycles; and yearly medians for interannual variations and trends. The monthly median values of inorganic dissolved orthophosphate (Fig. 2) show the increase of peak concentrations, in winter, up to 1981 and their decline thereafter. Minimum concentrations after the spring phytoplankton blooms, or the excess phosphate not used by the blooms, indicate no clear trend. The monthly median values of nitrate (Fig. 3) show the increase of peak concentrations in winter as well as of minimum concentrations in summer. Silicate concentrations (Fig. 4) declined until 1986, after peak values following Elbe river floods in 1975. Then a dramatic increase was found after the Elbe river floods in 1987.

The annual median values of phosphate and nitrate concentrations (Fig. 5) show more clearly the different development of the two major nutrient elements in the past three decades. The phosphate eutrophication started right from the beginning of the time-series in the 'sixties - following the introduction of detergents on a larger scale. Almost a doubling of concentrations was reached after a decade, a levelling off for another decade and a subsequent decrease to almost the original concentrations, over the last years. Nitrate concentrations, however, increased much later (in the 'eighties only), to reach three times the former level within a few years. A decrease was observed over the last 2 years.

It is necessary to differentiate between winter and summer nutrient concentrations, as these represent the situation of accumulated nutrient stocks before the spring phytoplankton bloom on the one hand, and the "regenerated nutrient" condition in summer, when nutrient concentrations are the result of the difference between remineralisation and consumption processes. Figures 6 and 7 show - besides the yearly median values the medians of winter (January-March) and summer (June-August) values. The increase of phosphate (Fig. 6) is larger in summer, under regenerated nutrient conditions, while the rise of nitrate concentrations (Fig. 7) is more evident in winter.

Due to the different development of phosphorus and nitrogen eutrophication, the nutrient ratios in the German Bight have changed markedly (Fig. 8). A regular year-cycle of the N/P-ratio is normal, with a P-surplus in summer and an $\mathrm{N}$-surplus in winter, as compared with the "normal" ratio of $N / P=16$, the "Redfield ratio". This is because the phosphate remineralisation proceeds faster than the nitrogen remineralisation, therefore phosphate concentrations increase faster (after the minimum following the spring phytoplankton blooms) than nitrate concentrations. As early as May, phosphate concentrations are rising, while nitrate concentrations are still declining. While this used to result in a phosphorus surplus in summer, now even in summer the $\mathrm{N}$-surplus remains, due to the large surplus of nitrate in winter which is not used up by the phytoplankton. The ammonia concentrations, which have decreased during the last two decades - as they did in Dutch coastal waters (Schaub \& Gieskes, 1991), are of decreasing quantitative importance for the inorganic nitrogen stock in the waters around Helgoland. Typical monthly median values in the last decade range from 1.5 to $6 \mu \mathrm{mol} \mathrm{dm}{ }^{-3}$.

The winter concentrations of nitrate (Fig. 7) are very high, which is particularly evident in the years of high Elbe river discharge (1981, 1987, 1988; cf. also Fig. 1). The rise of nitrate concentrations since 1981 was correlated with Elbe river discharge volumes; therefore a close negative correlation between nitrate and salinity was found, 


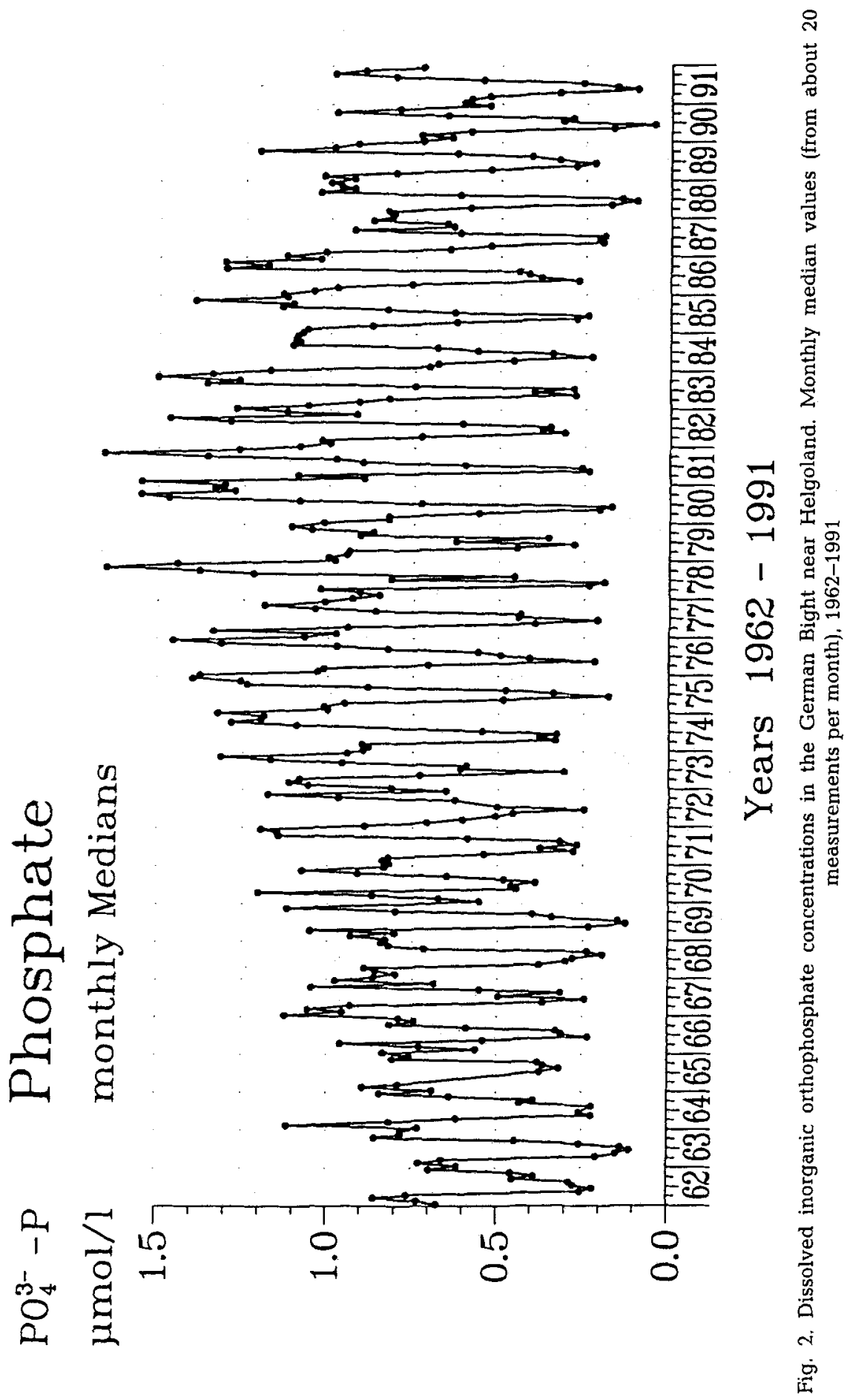




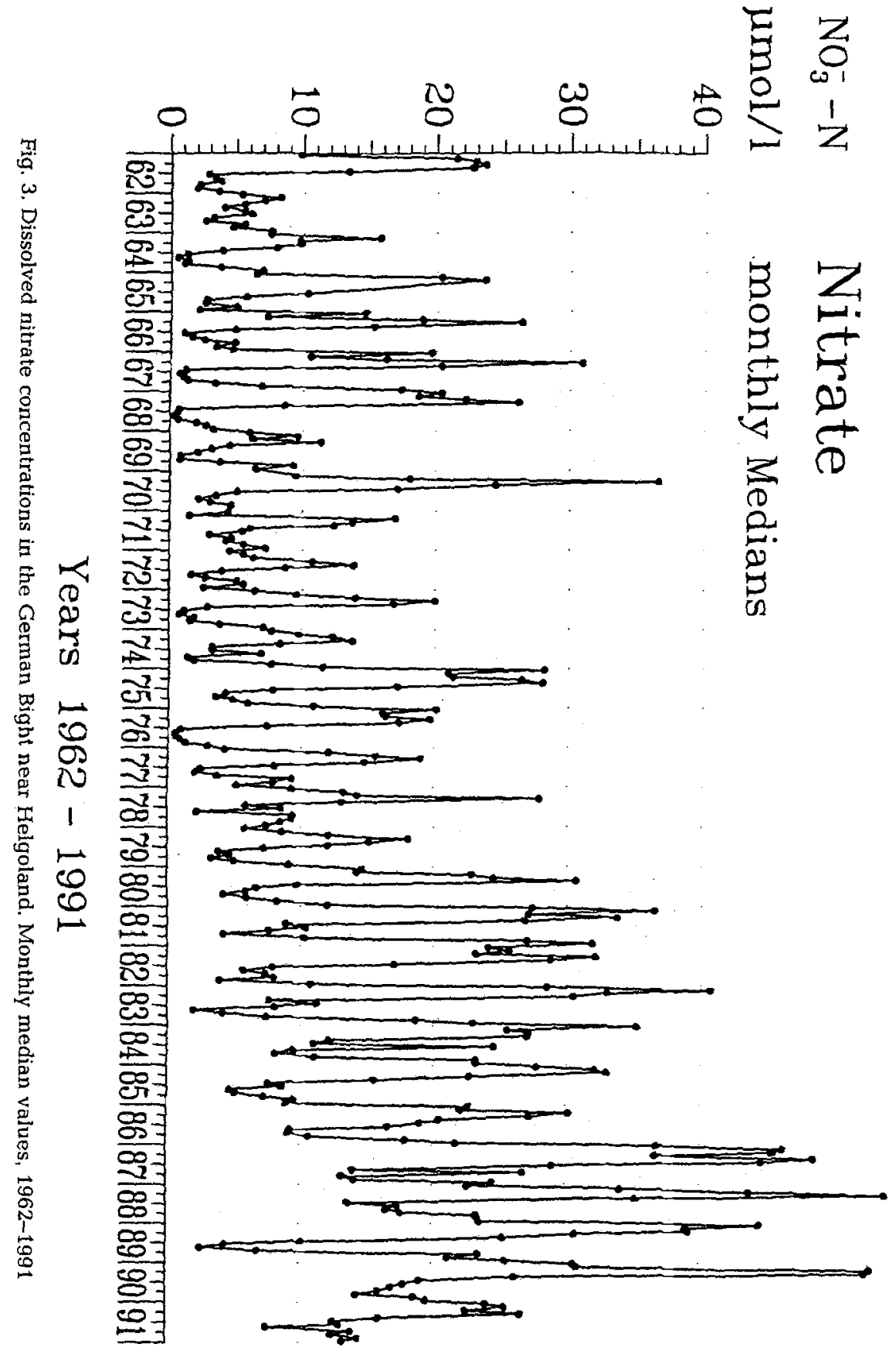




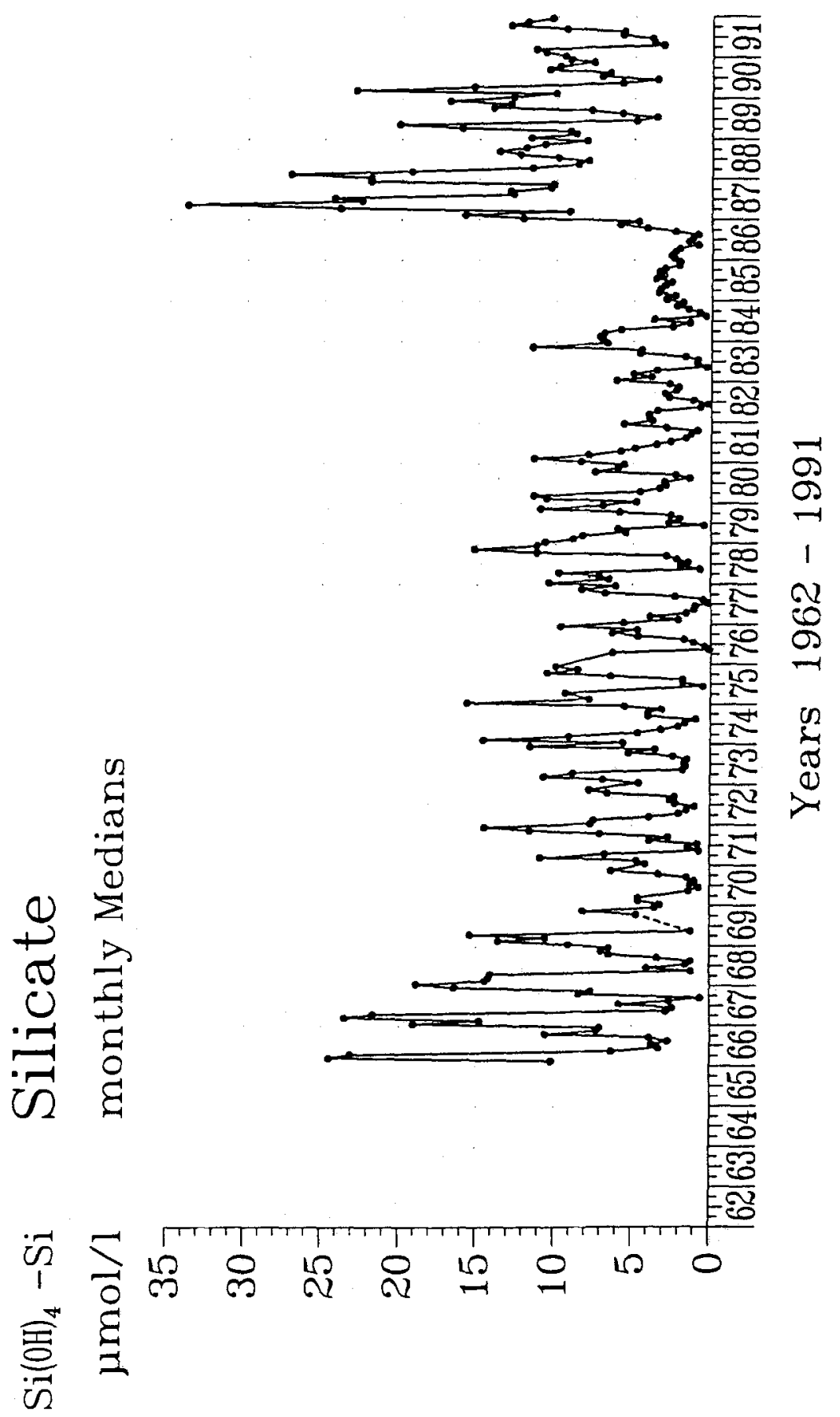




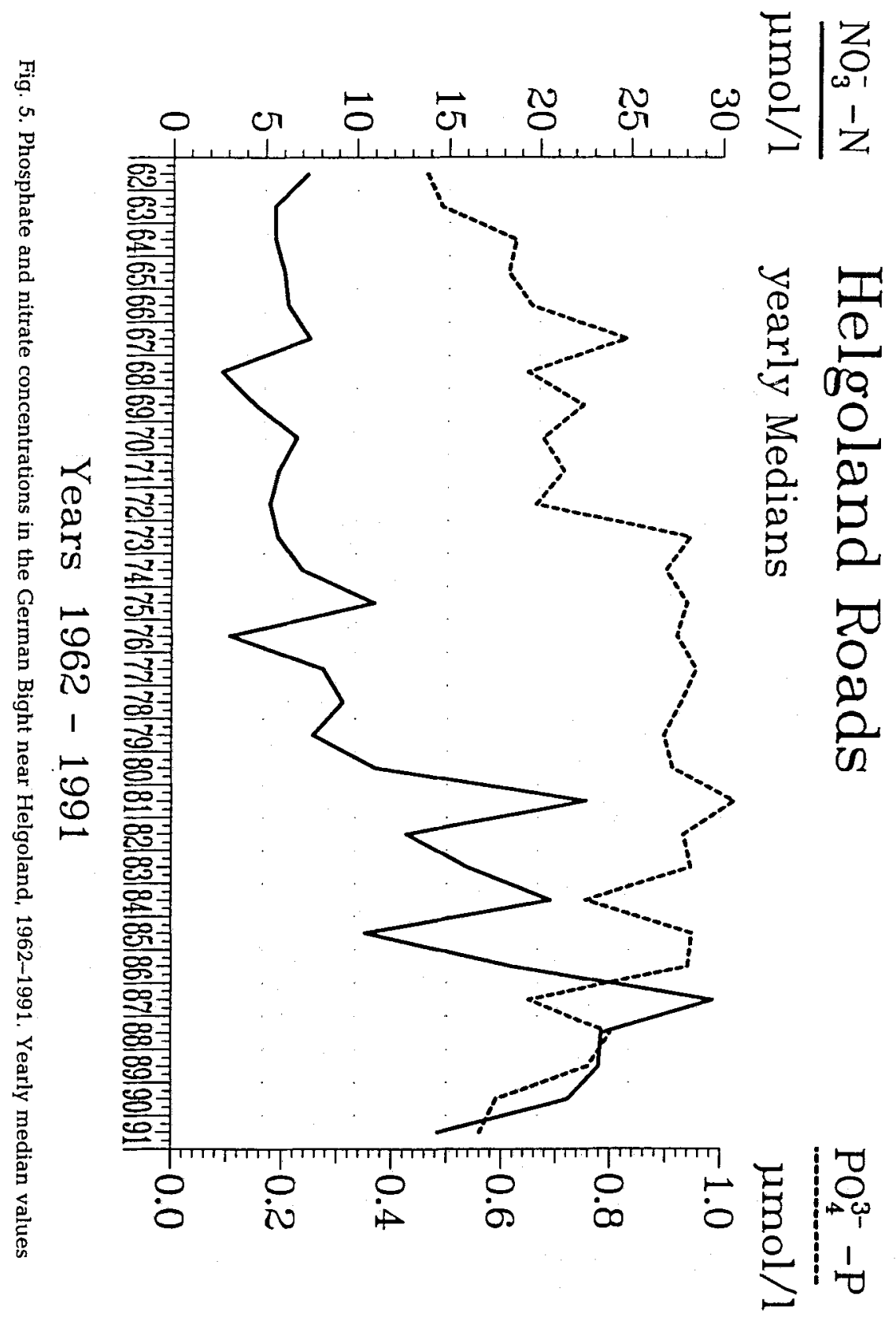



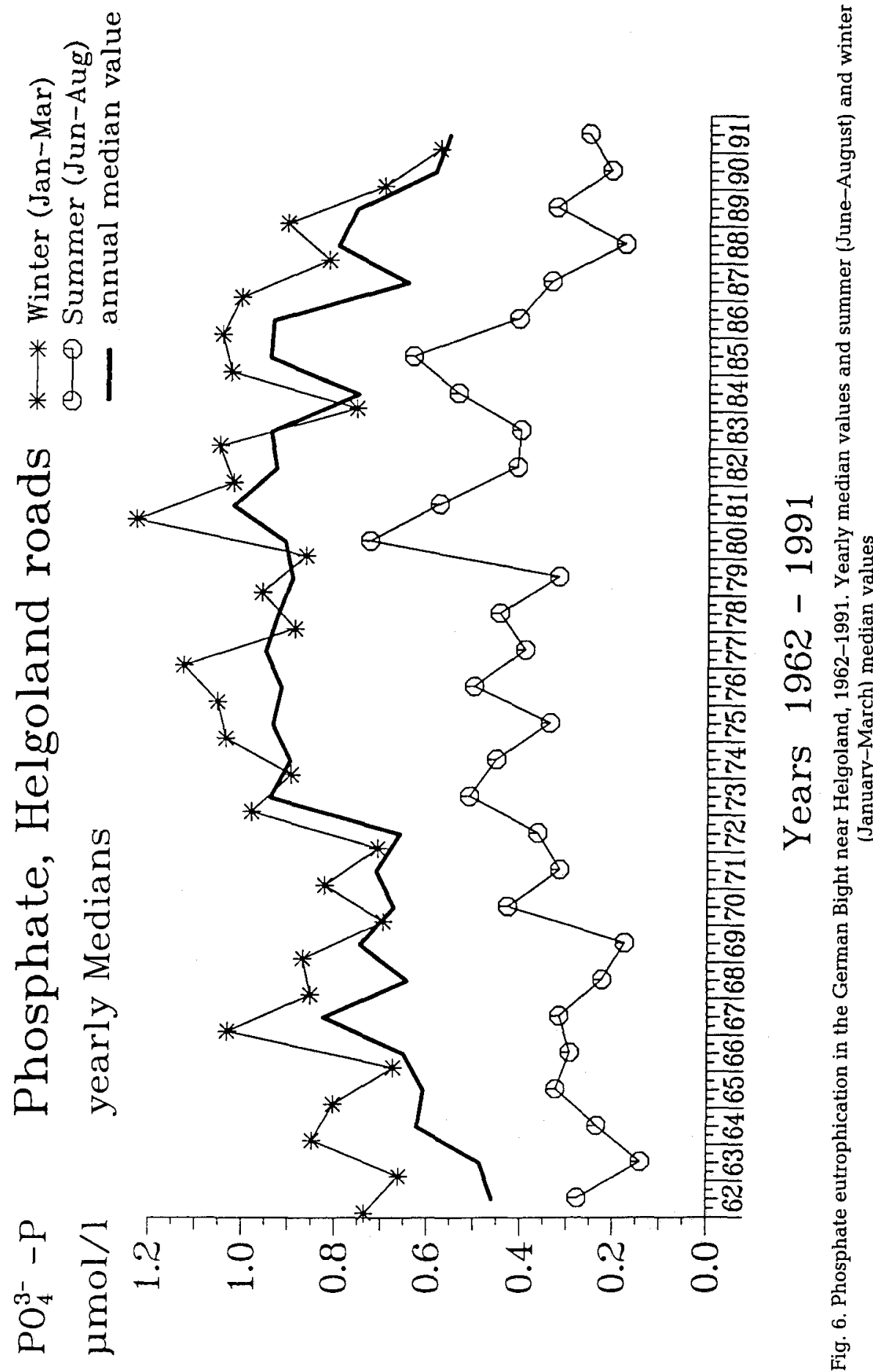


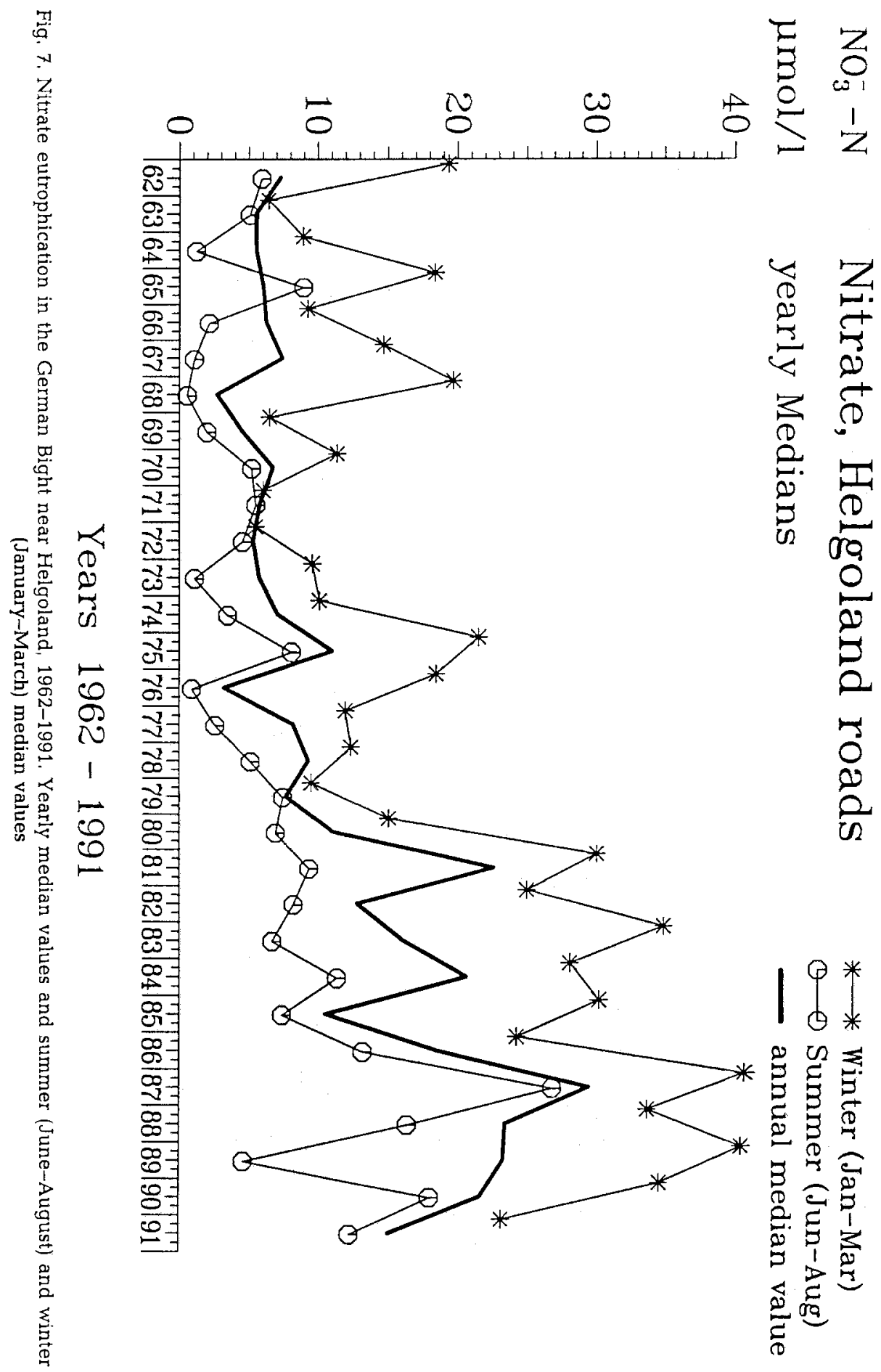



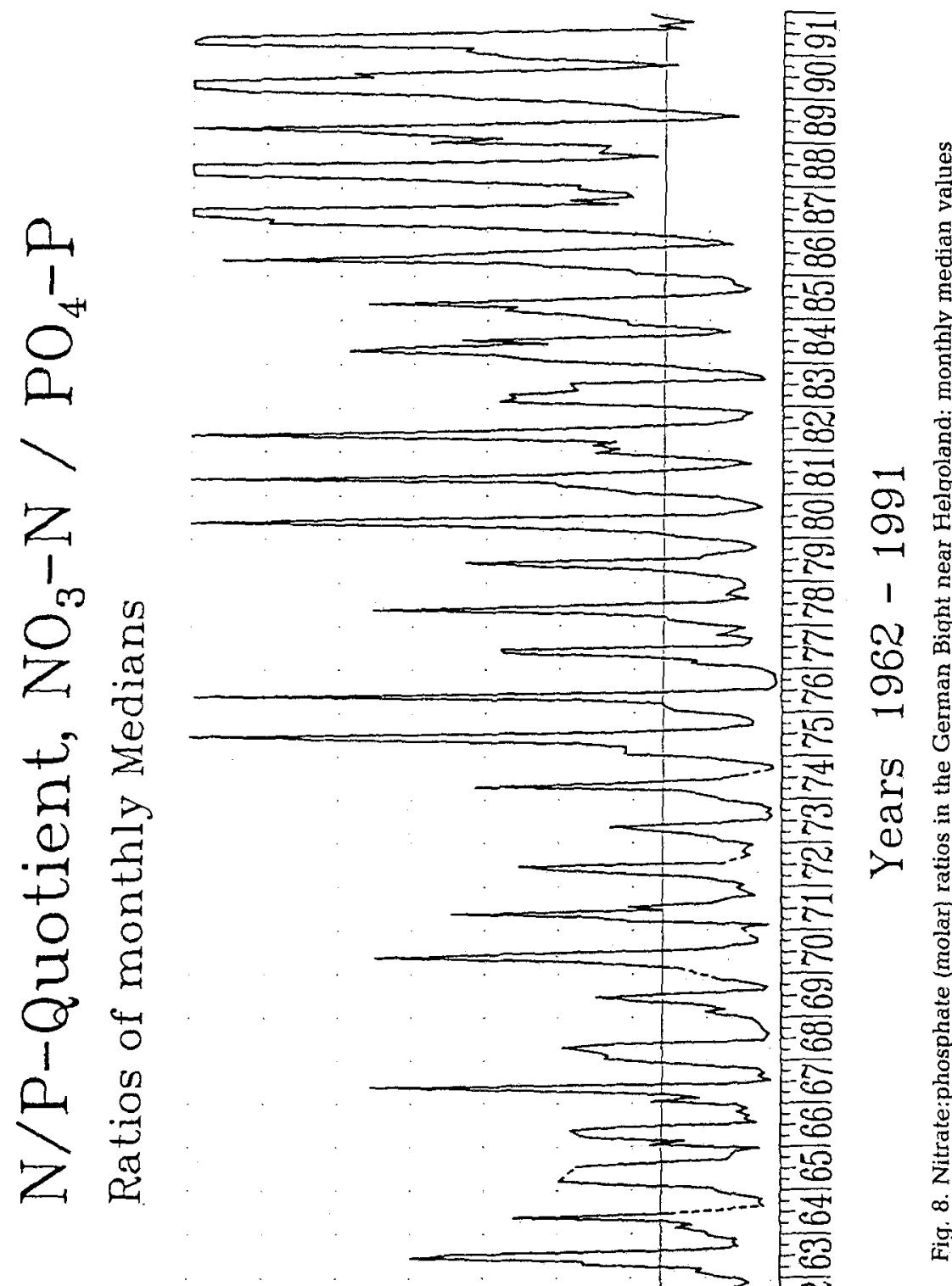

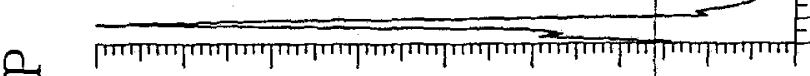

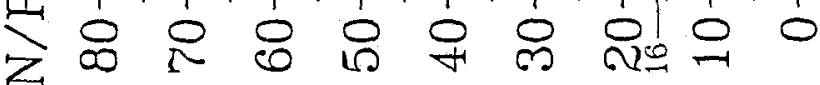


and this correlation extends farther out into the German Bight than the phosphatesalinity correlation does. The impact of large Elbe river floods on nutrient levels near Helgoland is shown in Figure 9, by comparing the years 1987 and 1988 (with large flood events) with the decade before. In 1987 and 1988, with almost twice as much Elbe water discharge than normal, approximately a doubling of nitrate concentrations was found. The increase in silicate concentrations was even greater: up to ten times more in May/ June than in the years before. Phosphate concentrations, however, were not elevated.

\section{DISCUSSION}

The difference in phosphate and nitrate eutrophication is thus most conspicuous and must be traced back to the main source, the River Elbe. Many years of monitoring of the Elbe water by the Wassergütestelle Elbe (ARGE Elbe, 1990, 1991) have shown the different behaviour of phosphate and nitrate in relation to the river water discharge volumes (Fig. 10, see also Lucht \& Gillbricht [1978]). Phosphate concentrations follow the theoretical dilution curve; therefore the contribution of rainwater and wash-out from the land cannot be very important. Nitrate concentrations, in contrast, do not follow the dilution curve, but increase in concentration with increasing rainfall and river discharge.

While inorganic dissolved phosphate behaves like a (constant) point source, following the dilution curve (Fig. 10), inorganic nitrogen comes mainly from diffuse sources and depends on wash-out by rainfall. The agricultural runoff of excess fertilizer is a known nitrogen source in the rivers. In Germany, nitrogen fertilizer use has increased considerably ( $3-4$ times) during the last decades (ARGE Elbe, 1990), while the use of phosphorus fertilizer has not. Besides this source of nitrogen, wet deposition of airborne nitrogen from car exhausts and intensive cattle breeding increasingly adds to the nitrogen load of the rivers. Direct wet deposition on the sea surface is becoming a significant $\mathrm{N}$-source, but is thought to be of minor importance for the coastal water, with its high nutrient level.

While riverine sources might explain rising concentrations of nitrogen in the coastal water, the delayed nitrate-eutrophication process is less clear: nitrate concentrations increased about a decade later than phosphate concentrations. This raises the question of whether the adsorptive capacity of soil particles for inorganic nitrogen had to first be reached, in order to release inorganic nitrogen into the groundwater and the rivers. Such a process could explain the unexpectedly rapid rate of the nitrate increase.

The silicate concentrations seem to depend a lot on discontinuous injections by large Elbe river floods which can obviously lead to an increase in silicate concentrations of 3-10 times. Additional data on horizontal gradients of $\mathrm{Si}$, corresponding to those of salinity, show that the River Elbe is indeed the main source of elevated silicate concentrations (Hickel et al, 1989). In between flood events, silicate concentrations decrease from year to year, making the role of silicate, as the first nutrient to be exhausted in the year cycle, more and more likely.

How far out into the North Sea can the eutrophication be measured? It is a generally recognised statement that the salinity of 33 psu delimits the coastal water where increased nutrient concentrations from riverine sources are found (Report of the Expert Group on nutrients. Oslo and Paris Commission (Colijn et al., 1992]). This was tested using the samples from Helgoland time-series with a salinity $\geqq 33$ psu. Only the winter values (from December through to February) were taken, for minimal interference with 

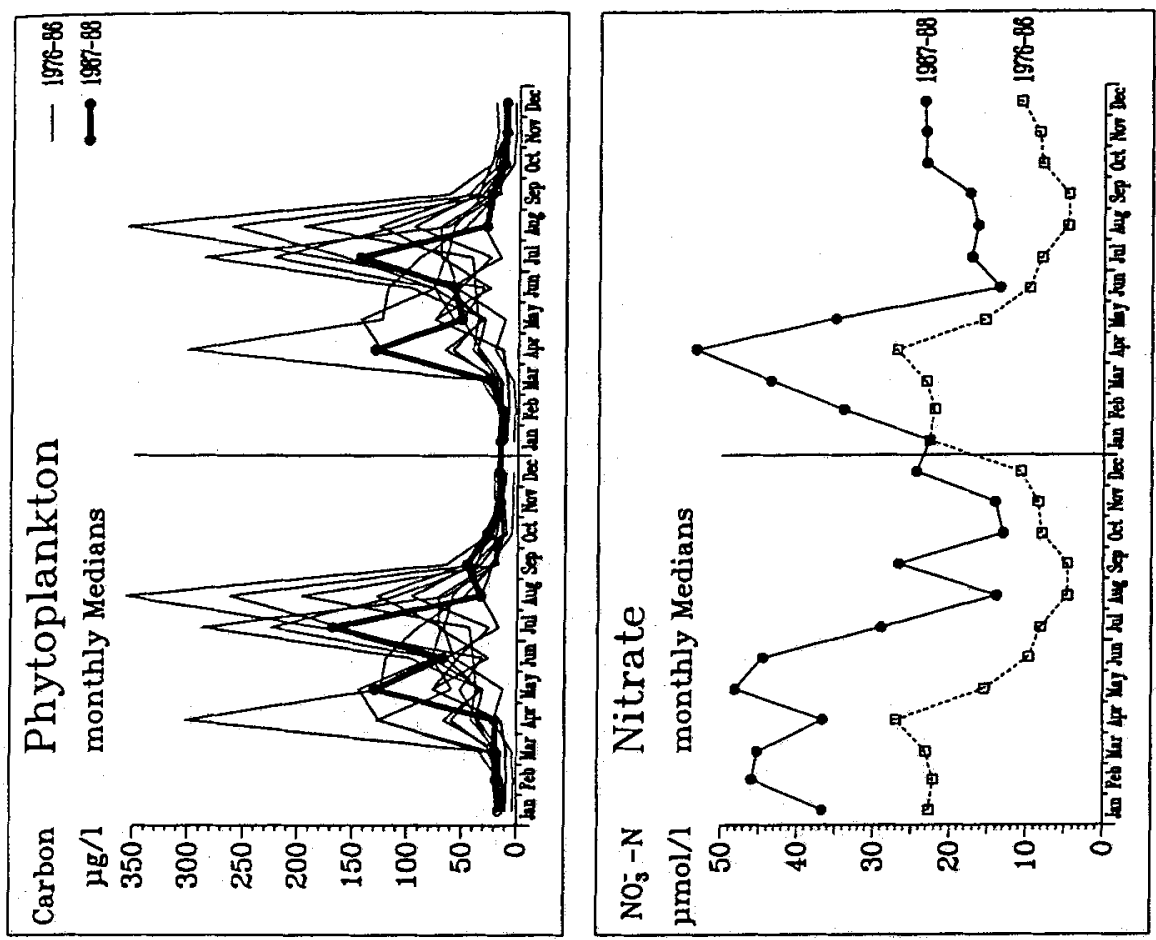

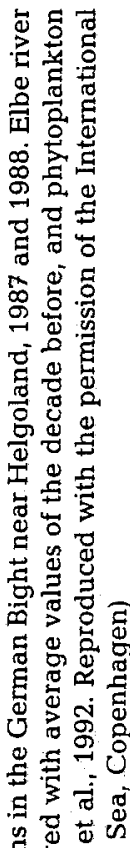

造总

昰究
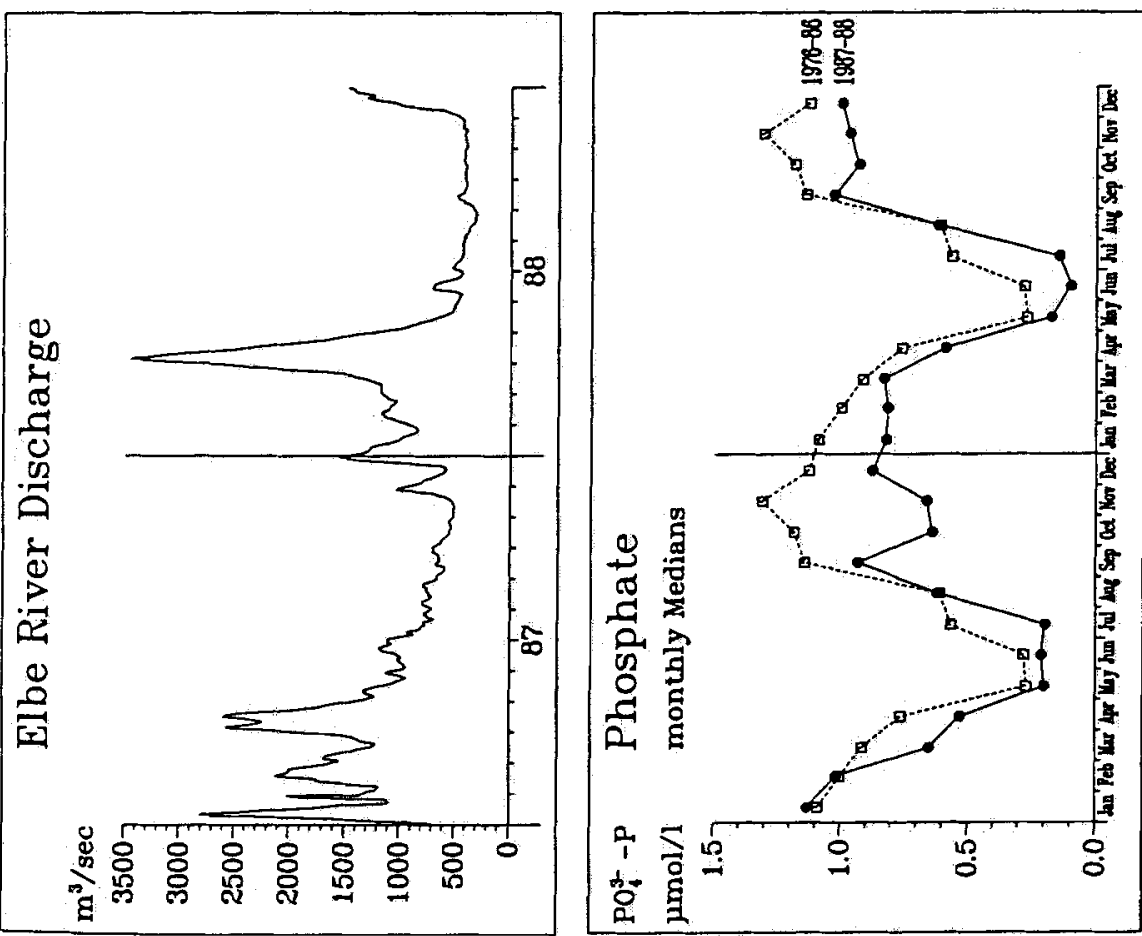

is 8

政

동응

녹 要

동

은 웡 总

官

홀

궁

.

品

둥 क्ष

요욜

8

要它

过

它吉

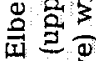

웡

를

훙응

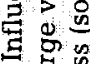

क)

نे 

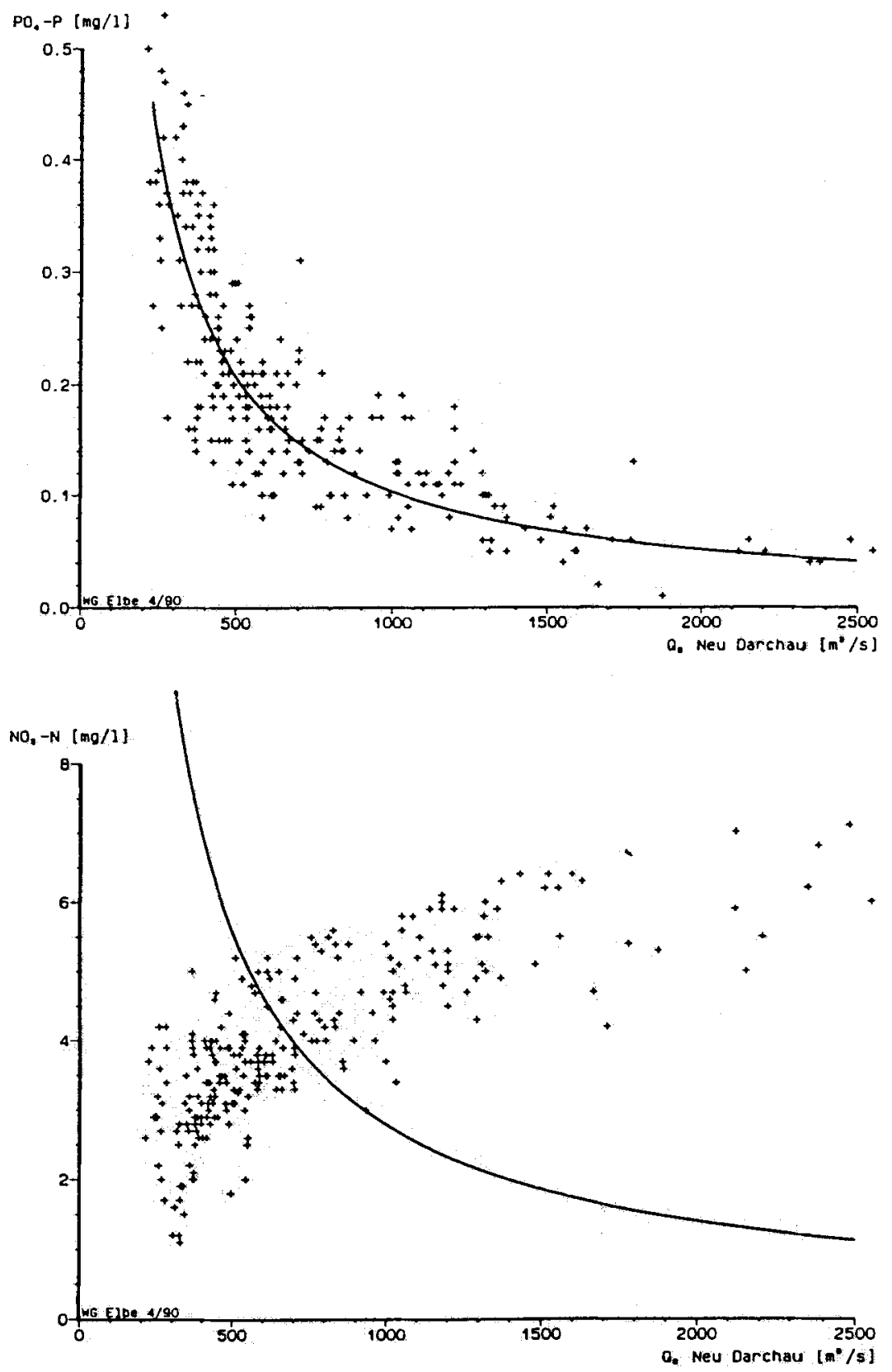

Fig. 10. Phosphate (upper) and nitrate (lower graph) concentrations in the Elbe river water in relation to the Elbe discharge volume (from: ARGE Elbe, 1990) 
biological processes. Salinities of $\geqq 33$ psu represent the water of the outer German Bight, well outside the direct influence of the Elbe river water plume (Hickel, 1980). Figures 11 and 12 show the nutrient concentrations as mean values of the respective winters (with $95 \%$ confidence intervals and no. of values); the result is that the above assumption must be rejected. The increase in phosphate and nitrate concentrations are similarly large in the water of $S \geqq 33$ psu, but their peak concentrations occurred 3 years later than in the average Helgoland data. Maximum concentrations in the high-salinity water were found in winter $1975 / 76$ for phosphate, and $1983 / 84$ for nitrate. Compared with the yearly average values from Helgoland, the increase of phosphate in the water with $S \geqq 33$ psu occurred even about a decade later.

As the eutrophication of the outer German Bight (represented by salinities of $\geqq 33$ ) occurs later and is disconnected from reduced salinities, it seems likely that nutrients were carried by plankton and detritus (organic seston), going through cycles of sedimentation and remineralization - which could explain the delay. This assumption becomes more credible as other evidence points to the same direction: the northernmost German Wadden Sea basin (of Sylt) also showed a very delayed eutrophication (Hickel, 1980, 1989), which can be explained by nutrient transports as organic seston.

Other evidence for long-distance transport of organic particles along the residual current direction comes from the site of the oxygen depletion in the bottom water of the south-eastern North Sea. Extended areas of severe oxygen shortage have been found there since the early 'eighties, far away (about $100 \mathrm{~km}$ and more) from potential sources of nutrient input (von Westernhagen et al., 1986). Settling phytoplankton in the bottom water was found concentrated farther north, in the direction of the residual currents, than blooms of the same species in the surface waters (Hickel et al., 1989).

This paper describes the human impact in the German Bight, using nutrient and phytoplankton data from the Helgoland time-series. The anthropogenic influence on nutrient concentrations and ratios can be demonstrated the increase of phosphate levels during the sixties and early 'seventies, the phosphate decrease as a result of P-reducing measures, and the late increase in nitrate in the eighties, led to a marked shift of the N:P-ratios.

While the human impact on the German Bight is clearly demonstrated in the case of inorganic nutrient increase, the impact on phytoplankton populations cannot be as well shown. The increase of phytoplankton stocks is not correlated with the increase of nutrients, as expected and as described for the eutrophying effect of the Rhine river in the Dutch coastal water (Schaub \& Gieskes, 1991). From yearly median values (Fig. 13) an increase of total phytoplankton biomass near Helgoland of about $3-4$ times is likely during the growth season of autotrophic phytoplankton. Differentiation between diatoms and flagellates - as yearly median values for their respective blooming periods - show that while diatoms might have increased in the first decade, the flagellates did increase later on, with large interannual differences, however. Additional chlorophyll (data from 1965-1978 [Hagmeier, unpublished data]) show maximum monthly median values of between 5 and $10 \mu \mathrm{g}$ chlorophyll a dm$~^{-3}$ in summer. Average phytoplankton carbon/ chlorophyll a-ratios of $36-42$ result from regressions of the data from the vegetation period, they are within the range given by Reid et al. (1990) for the Dutch coastal water. A rather high $Y$-intercept $\left(1.5 \mu \mathrm{g}\right.$ chlorophyll $\mathrm{dm}^{-3}$ in spring, $2.9 \mu \mathrm{g}$ in late summer) at PPC $=0$ could either be interpreted as "dead chlorophyll" bound in detritus, or as loss of phytoplankton e. g. by fixation. 


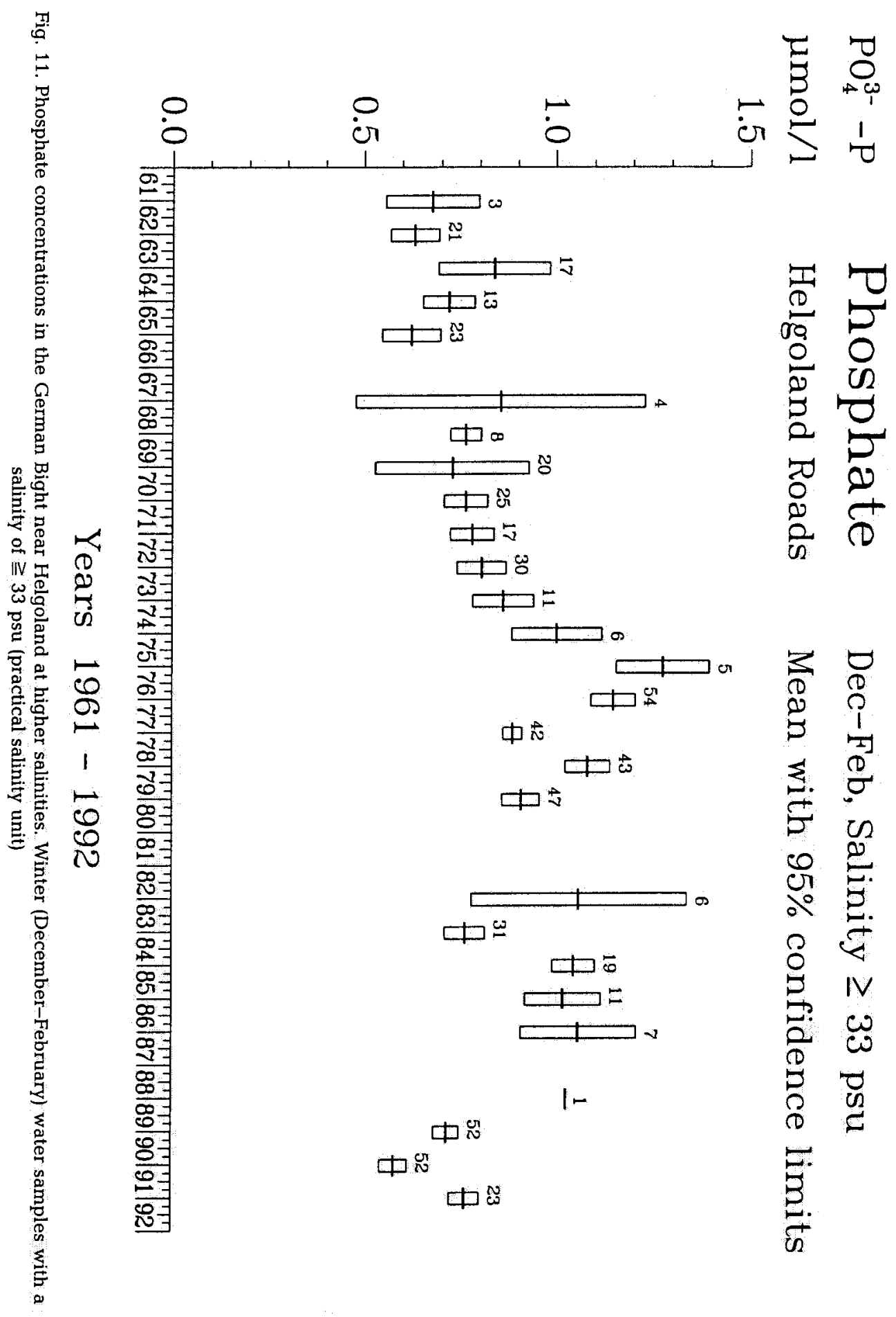




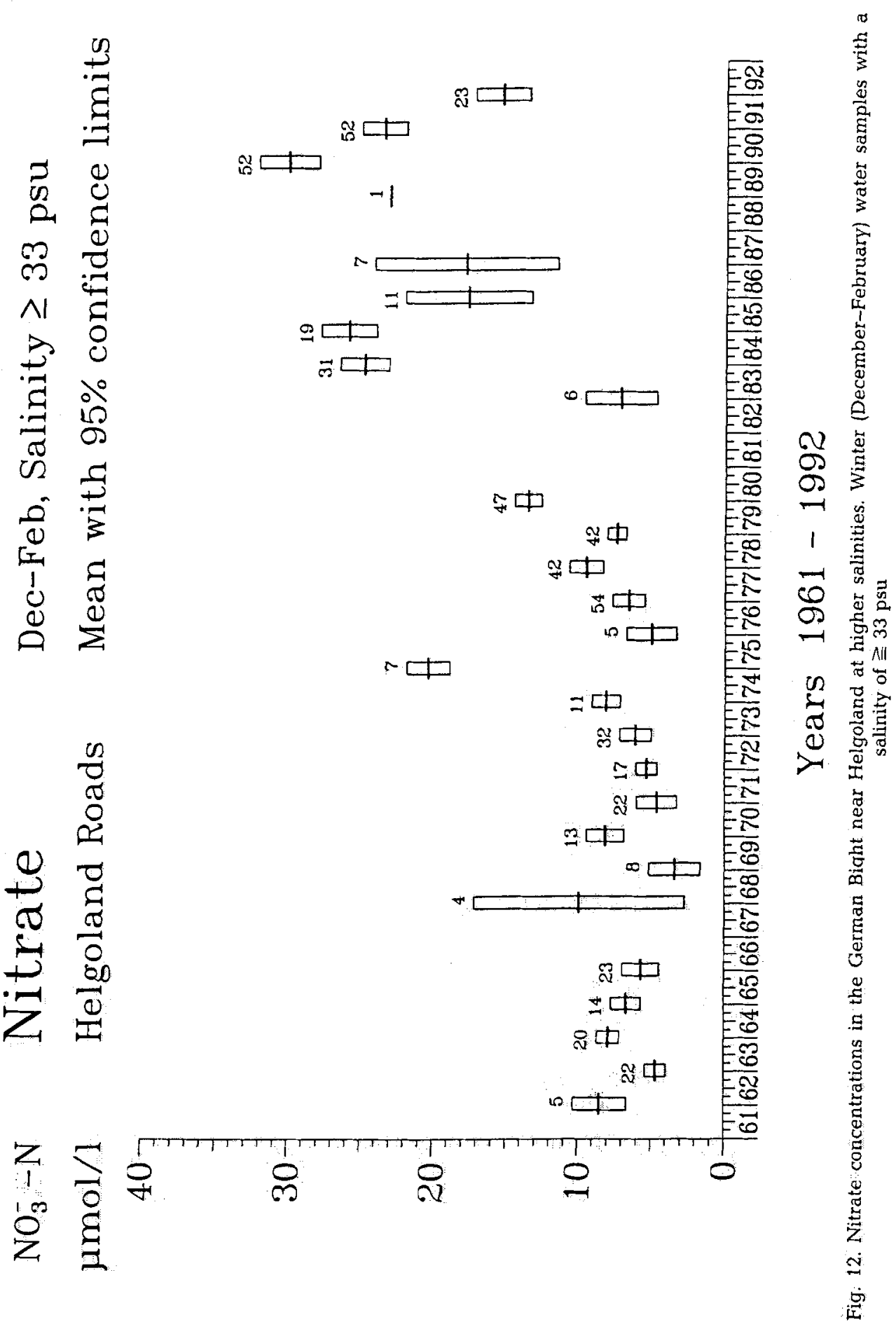



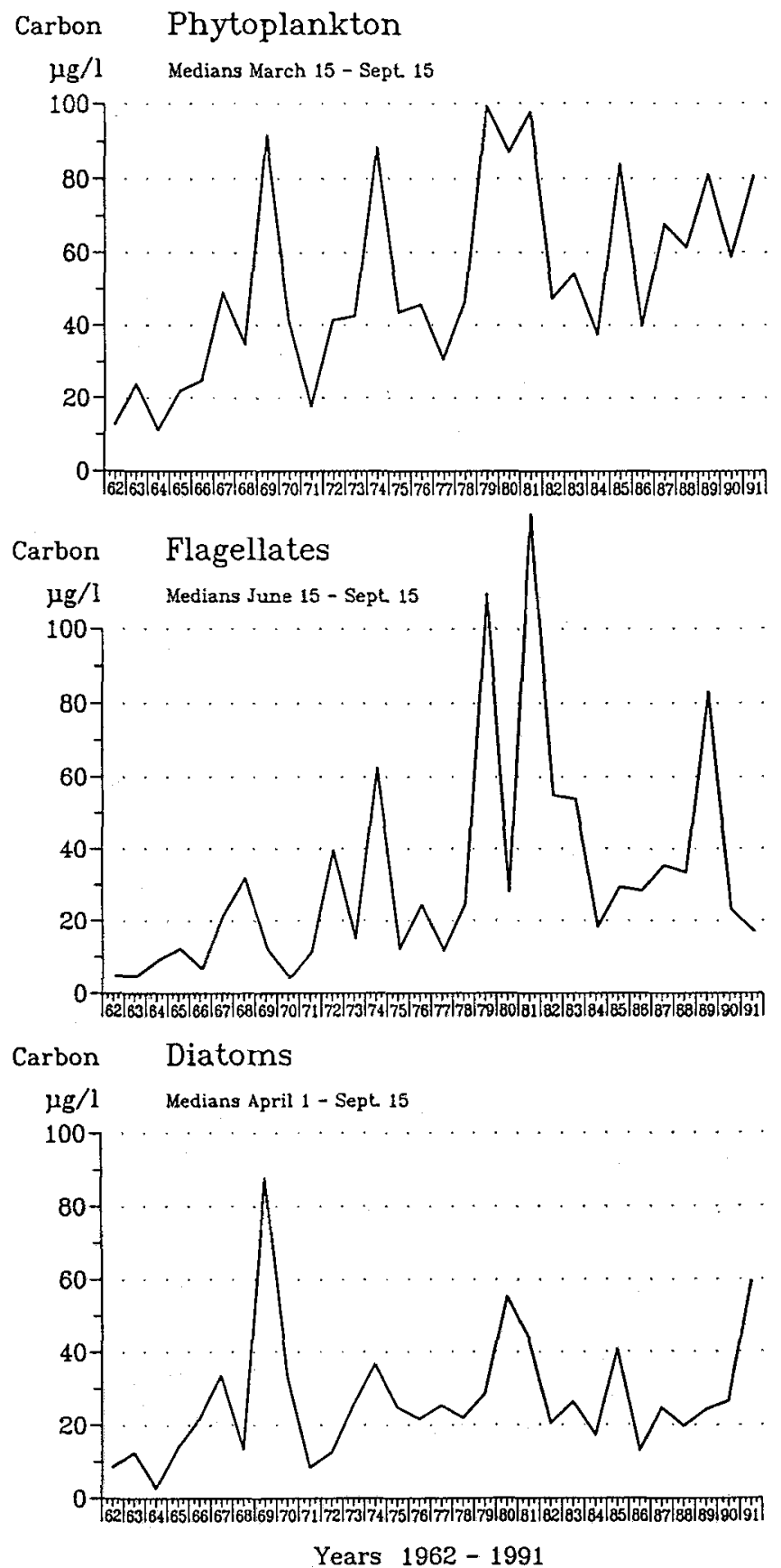

Fig. 13. Total phytoplankton biomass in the German Bight near Helgoland, 1962-1991: yearly median values of the growing season (mid-March - mid-September), upper graph. Flagellate and diatom biomass, median values for their respective main growing season (potential blooming periods) 
The observed increase in phytoplankton seems to be mainly due to naked nanoflagellates, which could not be identified in the preserved samples. These delicate species formed a large population of about $5 \mu \mathrm{g}$ of organic carbon $\mathrm{dm}^{-3}$ in the first half of the period and about $25 \mu \mathrm{g}$ in the last decade; these populations were remarkably constant throughout the year. Overall, the flagellates smaller than $10 \mu \mathrm{m}$ were about as numerous in winter as in summer. As light conditions in winter are poor, in the turbid, tidally-mixed Helgoland waters, it is unlikely that such a large and constant population of phototrophic flagellates could survive at this time. It is hard to believe that a net primary production of autotrophic phytoplankton could occur in winter; the lack of a significant diatom population in the Helgoland waters during that period also indicates this. Therefore the nanoflagellate population in the Helgoland waters should - at least in winter - be regarded as composed of the many known heterotrophic or mixotrophic species. The values in Figure 13 include the above-mentioned fraction of nanoflagellates of unknown trophic state.

In general, the nanoflagellate numbers cannot be considered as reliable as the numbers of armoured dinoflagellates and diatoms. This is because many of the minute, naked nanoflagellates tend to disrupt by fixation, which is well-known from the literature (e. g. Reid et al., 1990). Among the successfully preserved nanoflagellates, many might disintegrate later after some period of storage, but we have insufficient evidence of this effect in order to evaluate the present data: in the first half of the series, part of the plankton samples were stored for considerable (but varying) periods, contrary to the second half of the time-series, when plankton samples were stored for only a few days. Unnoticed losses by different storage periods might thus add to the observed changes in nanoflagellate stocks.

As mentioned above, the causal relationship between inorganic nutrient eutrophication and phytoplankton stocks is not clearly demonstrable from the Helgoland data. This is mainly because massive extra nutrient supply during large Elbe river flood events such as in the years 1987 and 1988 (Figs 13 and 9) - failed to enhance phytoplankton stocks near Helgoland. A comparison between two periods of large Elbe river floods might be helpful to explain possible reasons for differing response of phytoplankton to Elbe river floods (Hickel et al., 1992). While such flood events in winter and summer 1981 resulted in the largest phytoplankton (Ceratium) blooms ever recorded in the German Bight, winter/spring floods in 1987 and 1988 had no such effect. The difference was an extended period of calm weather in 1981, which, along with abundant freshwater inflow, led to a strong vertical density stratification, whereas in $1987 / 1988$ no such stratification was observed, due to windy weather. Hence, the improved light condition in a stratified water column was probably the dominant factor for the plankton blooms. The varying hydrographic structure of the German Bight might be the reason why the response of phytoplankton growth to eutrophication is so different from that in the Dutch coastal water influenced by the River Rhine (Schaub \& Gieskes, 1991).

In conclusion, the phosphate time-series at Helgoland (Fig. 2) shows that measures of reducing phosphate can be successful over a rather short period. In contrast to this easyto-manage point source, nitrate, as a diffuse source, will be more difficult to control. Its late increase, as compared with phosphate (Fig. 5), is not even sufficiently understood. The horizontal extent of eutrophication is larger than previously thought and this seems to be the result of nutrient transport in particulate form. Particulate organic matter as a 
major long-distance carrier of nutrients must be further investigated, in order to understand mechanisms of eutrophication and pollution.

Phytoplankton stocks, as potentially enhanced by eutrophication, seem to have increased during their growth season. But a direct correlation with nutrient loads of the River Elbe was not found; it is rather the vertical density stratification that dominates the phytoplankton mass occurrence in summer, as an example from the year 1981 shows. Only if conditions of stratified water columns become more frequent, is it likely that the impact of eutrophication on phytoplankton will become more effective. But this effect will be found to be more pronounced in the outer German Bight waters, where nutrient concentrations in summer are closer to growth-limiting levels than near Helgoland. Such effects are not sufficiently monitored with the Helgoland Roads time-series, and additional regionally extended time-series would be required.

Acknowledgements. We want to thank all those who continued the tedious work on the Helgoland time-series samples for decades, particularly Dr. E. Hagmeier, who counted most of the plankton in the first half, and $\mathrm{K}$. Treutner, who counted in the second half of the time-series.

\section{LITERATURE CITED}

ARGE Elbe, 1990. Nährstoffstudie der Elbe. ARGE Elbe, Hamburg, 53 pp.

ARGE Elbe, 1991. Trend-Entwicklung der Nährstoffe im Elbwasser von 1980-1989. ARGE Elbe, Hamburg, 23 pp.

Brockmann, U., Billen, G. \& Gieskes, W. W. C., 1988. North Sea nutrients and eutrophication. In: Pollution of the North Sea. Ed. by W. Salomons, B. L. Bayne, E. K. Duursma \& U. Förstner. Springer, Berlin, 348-389.

Colijn, F., Dooley, H., Owens, N. J. P. \& Skjoldal, H. R., 1992. Report of the Expert Group on nutrients to Paris Commission Working Group on nutrients. Oslo and Paris Commn., Oslo, 1-27 (1/14/2E).

Gerlach, S. A., 1990. Nitrogen, phosphorus, plankton and oxygen deficiency in the German Bight and in Kiel Bay. - Kieler Meeresforsch. (Sonderh.) 7, 1-341.

Gillbricht, M., 1983. Eine "red tide" in der südlichen Nordsee und ihre Beziehungen zur Umwelt. Helgoländer Meeresunters. 36, 393-426.

Gillbricht, M, 1988. Phytoplankton and nutrients in the Helgoland region. - Helgoländer Meeresunters. $42,435-467$.

Grasshoff, K, Ehrhard, M. \& Kremling, K. (Eds), 1983. Methods of seawater analysis. Verl Chemie, Weinheim, $419 \mathrm{pp}$.

Hagmeier, E., 1961. Plankton-Äquivalente. - Kieler Meeresforsch. 17, 32-47.

Hagmeier, E., 1978. Variations in phytoplankton near Helgoland. - Rapp. P.-v. Réun., Cons. int. Explor. Mer 172, 361-363.

Hickel, W., 1980: The influence of Elbe river water on the Wadden Sea of Sylt (German Bight, North Sea). - Dt. hydrogr. Z. 33, 43-52.

Hickel, W., 1989. Inorganic micronutrients and the eutrophication in the Wadden Sea of Sylt (German Bight, North Sea). In: Proceedings of the 21st European Marine Biology Symposium. Ed. by R. Z. Klekowski, E. Styczinska-Jurewicz \& L. Falkowski. Polish Academy of Science, Institute of Oceanology, Wroclaw, 309-318.

Hickel, W., Bauerfeind, E., Niermann, U. \& Westernhagen, H. von, 1989. Oxygen deficiency in the south-eastern North Sea: Sources and biological effects. - Ber. Biol. Anst. Helgoland 4, 1-148.

Hickel, W., Berg, J. \& Treutner, K., 1992. Variability in phytoplankton biomass in the German Bight (North Sea) near Helgoland, 1980-1990. - ICES mat. Sci. Symp. 195, 247-257.

Kalle, K., 1956. Chemisch-hydrographische Untersuchungen in der inneren Deutschen Bucht. - Dt. hydrogr. Z. 9, 55-65,

Lucht, F. \& Gillbricht, M., 1978. Long-term observations on nutrient contents near Helgoland in relation to nutrient input of the Elbe river - Rapp. P.-v. Réun. Cons. int. Explor. Mer 172, $358-360$. 
Nelissen, P. H. M. \& Stefels, J., 1988. Eutrophication in the North Sea. NIOZ-Rapp. 1988-4, 1-100.

Radach, G. \& Berg, J., 1986. Trends in den Konzentrationen der Nährstoffe und des Phytoplanktons in der Helgoländer Bucht (Helgoland Reede Daten). - Ber. Biol. Anst. Helgoland 2, 1-63.

Radach, G. \& Bohle-Carbonell, M., 1990. Strukturuntersuchungen der meteorologischen, hydrographischen, Nährstoff- und Phytoplankton-Zeitreihen in der Deutschen Bucht bei Helgoland. Ber. Biol. Anst. Helgoland 7, 1-425.

Radach, G., Berg, J. \& Hagmeier, E., 1990. Long-term changes of the annual cycles of meteorological, hydrographic, nutrient and phytoplankton time series at Helgoland and at LV Elbe 1 in the German Bight. - Cont. Shelf Res. 10, 305-328.

Reid, P. C., Lancelot, C., Gieskes, W. W. C., Hagmeier, E. \& Weichart, G., 1990. Phytoplankton of the North Sea and its dynamics: a review. - Neth. J. Sea Res. 26, 295-331.

Schaub, B. E. M. \& Gieskes, W. W. C., 1991. Eutrophication of the North Sea: the relation between Rhine river discharge and chlorophyll-a concentration in Dutch coastal waters. In: Estuaries and coasts: temporal and spatial intercomparisons. Ed. by M. Elliot \& J.-P. Ducrotoy. Olsen \& Olsen, Fredensborg, 85-90.

Westernhagen, H. von, Hickel, W., Bauerfeind, E., Niermann, U. \& Kröncke, I., 1986. Sources and effects of oxygen deficiencies in the south-eastern North Sea. - Ophelia 26, 457-473. 